\title{
116 競泳用水着の異方性材料モデルと数値シミュレーションによる設計方法の提案 Anisotropic Material Modeling of Competitive Swimwear and a Proposal of Design Method by Numerical Simulation
}

\author{
○学 田燠宙夢（筑波大院）学 永岡丈弥（筑波大院） \\ 島名孝次（ミズノ）大森一宽（ミズノ）正 松田昭博（筑波大）
}

\begin{abstract}
Hiromu TANABE, Graduate student, University of Tsukuba, tennoudai 1-1-1, Tsukuba, Ibaraki Takeya NAGAOKA, Graduate student, University of Tsukuba, tennoudai 1-1-1, Tsukuba, Ibaraki Takatsugu SHIMANA, Mizuno Corporation, Nanko-Kita 1-12-35, Suminoe-ku, Osaka Kazuhiro OMORI, Mizuno Corporation, Nanko-Kita 1-12-35, Suminoe-ku, Osaka Akihiro MATSUDA, University of Tsukuba, tennoudai 1-1-1, Tsukuba, Ibaraki
\end{abstract}

\begin{abstract}
The purpose of this study is development of a new design method for competitive swimwear by numerical simulation. Biaxial tensile loading tests were conducted to obtain the mechanical characteristics of competitive swimwear. The fabrics of competitive swimwear consist of chemical fiber. From biaxial tensile loading test results, the fabric has orthotropy and the stiffness of the fabric shows the graph like the two polygonal lines along with the increase of stretch. An anisotropic hyperelastic model was applied to the reproduction of mechanical characteristics of swimwear. The anisotropic hyperelastic model in this paper is able to adjust the axial and shear stiffness individually. Finite element simulation of tensile loading tests was conducted to show the applicability of the anisotropic hyperelastic model to competitive swimwear. The results of the simulation showed good agreement with that of tensile loading test. It is important to design a pressure given by stretch of competitive swimwear from the two viewpoints, the exercise performance and the burden to the heart function. FE simulation of the pressure using a cylinder model was conducted to show the applicability of our design method to competitive swimwear. The results of the simulation showed good agreement with that of pressure test in a practical range of competitive swimwear.
\end{abstract}

Key Words: Swimwear, Anisotropic, Finite Element Method

\section{1. 緒言}

現在の競泳用水着は，高い伸張性を有した繊維で作られて おり，ゴム材料のような弾性挙動を示し，身体を強く締め付 けることができる。それにより身体の振動を減らすことがで きるなどの理由から，流体抵抗が軽減され記録の短縮が可能 となる.さらに，水着素材は伸長方向によって岡性が変化す る異方性を示す。そのため，素材の張力や異方性を適切に配 置することにより，泳ぐ姿勢をサポートしつつ，水泳の挙動 に対して柔軟に伸縮することが可能であると考えられる。し かし，水着素材の力学的な特性についての工学的な検証はあ まり行われていない。

運動性能と心臓への負担の二つの観点から，身体を締め付 けるコンプレッション系ウェアの着圧を設計することは重要 である.青木ら(1)は, 大腿部の加圧を $10 \mathrm{mmHg}$ から $20 \mathrm{mmHg}$ の範囲で行うことで，長時閒の運動遂行に好影響をもたらす 可能性を示唆した。また，青木ら(1)は $40 \mathrm{mmHg}$ を超える加圧 は運動を継続するためには好ましくないことを示した。その ため, 競泳用水着の着圧を $20 \mathrm{mmHg}$ 以下に設計することは 重要な設計条件である.

本研究の目的は，数値シミュレーションによる競泳用水着 の新たな設計手法の開発である。そのためにまず，二軸引張 試験を実施し競泳用水着の力学特性を評価した、次に，水着 の力学特性を再現するために異方性超弹性モデルを尊入した. 異方性超弾性モデルの競泳用水着一の適用性を評価するため に，引張試験の有限要素解析を行った。また，円筒を用いた 着圧の測定を行い，数值シミュレーションによる本設計手法 の適用性を検討した。

\section{2. 異方性超弾性モデル}

異方性超弾性モデルは材料の力学特性をひずみエネルギー 関数 $W$ によって再現する，本研究では，次式で表される異 方性超弾性モデルのひずみエネルギー関数を導入した(2).

$$
\begin{aligned}
W & =C_{1}\left(\bar{I}_{1}-3\right)+C_{2}\left(\bar{I}_{2}-3\right)+p(J-1) \\
& +\frac{1}{4}\left[\frac{C_{I}^{1}}{d_{I}^{1}}\left\{\left(I_{4}^{1}\right)^{d_{I}}-1\right\}+\frac{C_{K}^{1}}{d_{K}^{1}}\left\{\left(K_{1}^{1}\right)^{d_{K}^{1}}-1\right\}\right] \\
& -\frac{1}{4}\left\{\left(C_{I}^{1}-C_{K}^{1}\right)\left(I_{4}^{1}-1\right)+C_{K}^{1} \ln \left(I_{3}\right)\right\} \\
& +\frac{1}{4}\left[\frac{C_{I}^{2}}{d_{I}^{2}}\left\{\left(I_{4}^{2}\right)^{d_{I}^{2}}-1\right\}+\frac{C_{K}^{2}}{d_{K}^{2}}\left\{\left(K_{1}^{2}\right)^{d_{K}^{2}}-1\right\}\right] \\
& -\frac{1}{4}\left\{\left(C_{I}^{2}-C_{K}^{2}\right)\left(I_{4}^{2}-1\right)+C_{K}^{2} \ln \left(I_{3}\right)\right\}
\end{aligned}
$$

ここで, $C_{I}^{1}, C_{I}^{2}, d_{l}^{1}, d_{I}^{2}, C_{K}^{\mathrm{l}}, C_{K}^{2}, d_{K}^{1}, d_{K}^{2}$ は材料定数である.この モデルは繊維の伸長方向とせん断の剛性をそれぞれ調整可能 である。また， $\bar{I}_{1}, \bar{I}_{2}, I_{3}, I_{4}^{1}, I_{4}^{2}, K_{1}^{1}, K_{1}^{2}$ は，次の様な右 Cauchy-Green テンソルC に関する不変量である.

$$
\begin{aligned}
& \bar{I}_{1}=\overline{\boldsymbol{C}}: \boldsymbol{I}=I_{3}^{-1 / 3} \boldsymbol{C}: \boldsymbol{I} \\
& \bar{I}_{2}=\left(\overline{\boldsymbol{C}}^{-1} \operatorname{det} \overline{\boldsymbol{C}}\right): \boldsymbol{I}=\left(\left(I_{3}^{1 / 3} \boldsymbol{C}^{-1}\right) \operatorname{det}\left(I_{3}^{-1 / 3} \boldsymbol{C}\right)\right): \boldsymbol{I} \\
& I_{3}=\operatorname{det} \boldsymbol{C} \\
& I_{4}^{1}=\boldsymbol{C}: \boldsymbol{M}^{1}, \quad I_{4}^{2}=\boldsymbol{C}: \boldsymbol{M}^{2} \\
& K_{1}^{1}=\left(I_{3} \boldsymbol{C}^{-1}\right): \boldsymbol{M}^{1}, \quad K_{1}^{2}=\left(I_{3} \boldsymbol{C}^{-1}\right): \boldsymbol{M}^{2}
\end{aligned}
$$

ここで， $M^{1}$ と $M^{2}$ はそれぞれ， $M^{1}=a \otimes a, M^{2}=b \otimes b$ と 定義される構造テンソルである。 ベクトル $\boldsymbol{a}$ と $\boldsymbol{b}$ はそれぞれ 縦系と横糸に平行な単位バクトルである.

第 2 Piola-Kirchhoff 応カテンソル $\boldsymbol{S}$ は，ひずみエネルギー 関数 $W$ を右 Cauchy-Green テンソル $C$ で偏微分することに より得られる。

$$
\begin{aligned}
& \boldsymbol{C}=\boldsymbol{F}^{t} \cdot \boldsymbol{F} \\
& \boldsymbol{S}=2 \frac{\partial W}{\partial \boldsymbol{C}}
\end{aligned}
$$


なお， $\boldsymbol{F}$ は初期時刻 $t_{0}=0$ での初期配置におうりる物質点 $\boldsymbol{X}$ と， 現時刻 $t$ での現在配置にお忷る物質点 $\boldsymbol{x}$ により, 次の様に定 義される変形勾配テンソルである。

$$
F=\frac{\partial x}{\partial X}
$$

\section{3. 二軸引張試験}

\section{1 試験片と試験方法}

競泳用水着の力学特性を評価するために二軸引張試験を行 った．試験片の左右を固定し，上面に引張変形を与えた。試 験片の寸法は, $50 \mathrm{~mm}$ 四方とし, 厚さは $0.2 \mathrm{~mm}$ である. 縦禾 と引張方向のな方角度を瀻維配向角 $\theta$ と仮定した. 異方性を 考慮するために， $0^{\circ} ， 15^{\circ} ， 30^{\circ} ， 45^{\circ} ， 60^{\circ} ， 75^{\circ}, 90^{\circ}$ の 7 種類の試験片で二軸引張試験を行った。 なお, 変位速度

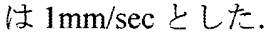

\section{2 数值シミュレーション}

異方性超弹性モデルの水着素材いの適用性を示すために, 二軸引張試験の有限要素解析学行った. 左右を拘束し, 上面 に引張変形を与えた。

解析結果と実験結果の公称忘力と公称伸びの関係を Fig. 1(a) と Fig. 1(b)に示京. Fig. 1(a)には繊維配向角 $\theta$ が $0^{\circ} ， 15^{\circ}$ ， $30^{\circ} ， 45^{\circ}$ ，Fig. 1(b)に戊繊維配向角 $\theta$ が $45^{\circ} ， 60^{\circ} ， 75^{\circ}$, $90^{\circ}$ の結果を示す．全ての瀻維配向角において, 解析結果と 実䮠結果は良い一致を示した。 それにより，本解析モデルに よって，競泳用水着の力学特性が再現可能であると言える。

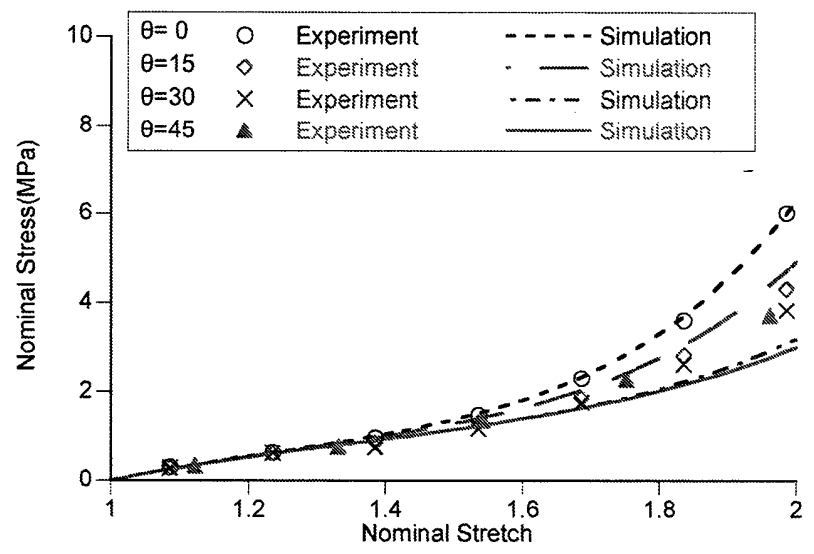

(a) $\theta=0^{\circ}, 15^{\circ}, 30^{\circ}, 45^{\circ}$

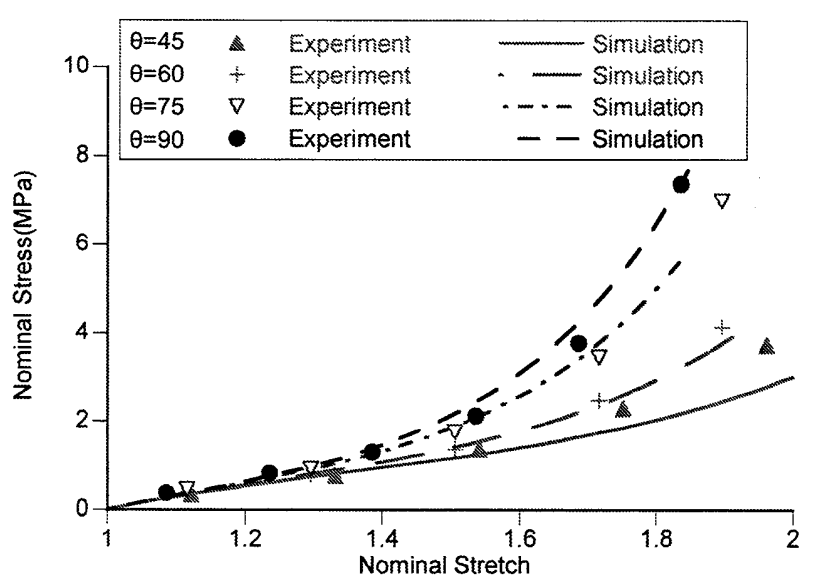

(b) $\theta=45^{\circ}, 60^{\circ}, 75^{\circ}, 90^{\circ}$

Fig. 1 Comparison with biaxial tensile loading test and $\mathrm{FE}$ simulation by nominal stress

\section{4. 着压測定}

\section{1 試験片と試験方法}

着圧を測定することは，競泳用水着の性能を評価するのに 重要である。そのため，アクリルの円筒を用いて着圧を測定 した.円筒の寸法は, 太ももの円周に近い直径 $150 \mathrm{~mm}$ とした. 3 種類の試験片を用いて測定を行った。試験片の幅は全て $150 \mathrm{~mm}$ とし，円周は $150 \mathrm{~mm}$ の円筒に装着した際に，公称伸 びが $1.2 ， 1.4 ， 1.6$ となるようにした．縦系と円筒の長手方向 のなす角度を繊維配向角 $\theta$ と仮定し, 試験片の角度は全て $90^{\circ}$ とした。

\section{2 数值シミュレーション}

数値シミュレーションによる本設計手法の適用性を評価す るために，着王測定の有限要素解析を行った，解析の円筒モ デルを Fig. 2(a)に示す. 加えて, 解析と実験を比較するため に，着压試験の様子を Fig. 2(b)に示す．円筒モデルの幅は $150 \mathrm{~mm}$ で，最終直径は $150 \mathrm{~mm}$ である。内面に半径が拡大寸 る方向に変形を与えた。圧力と公称伸びの関係を実験結果と 共に Fig. 3 に示す. 解析結果は公称侧び 1.4 から 1.6 の範囲で 良い一致を示した。

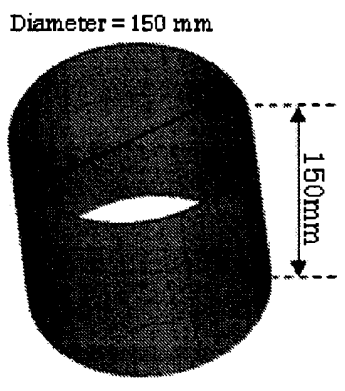

(a)

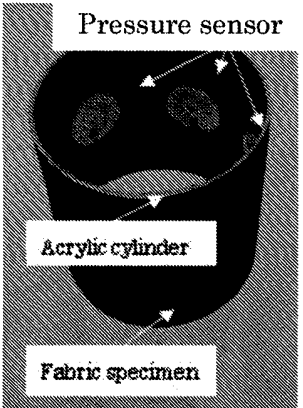

(b)
Fig. 2 (a) FE simulation of radial extension $(36 \times 3 \times 2$ elements) (b) Pressure test

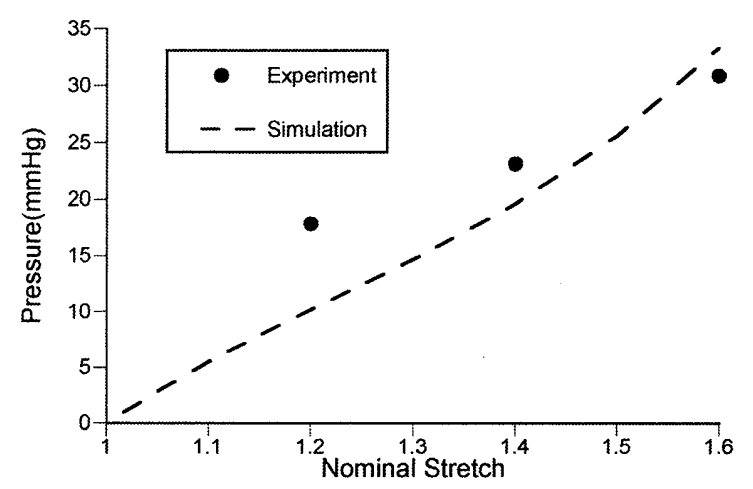

Fig. 3 Comparison with experiment and FE simulation

\section{5. 結言}

競泳用水着の力学特性を再現できる異方性超弾性モデルと 数值シミュレーションによる競泳用水着の設計手法を提案し た。 その結果, 解析結果は実験結果と良い一致を示し, 異方 性材料モデルと本設計手法の適用性が示された。これらの数 值シミュレーションをより高度化することにより，力学的根 拠に基づく競泳用水着の設計を行うことが可能となる.

\section{参考文献}

（1）青木美枝，吉澤正尹，三澤利博，浜田敏彦：スポーツウェ アによる皮膚圧迫と運動パフォーマンスに関古る基礎的研究， デサントスポーツ科学, Vol.17, pp.296-305, 1996.

(2) 浅井光輝, 木村嘉之, 園田佳巨，西本安志，西野好生：異 方性粘性・超弾性体による織布強化ゴムの構成式モデリング, 土木学会論文集 A, Vol.66, No.2, pp.194-205, 2010. 